\title{
THE ARGENTINE ECONOMY AFTER TWO CENTURIES*
}

\author{
Francisco BUERA** \\ Gastón NaVARro*** \\ JuAn Pablo Nicolini****
}

\begin{abstract}
We document the behavior of income per capita in Argentina subsequent to independence and the civil wars of the mid-19th century. We first decompose the data to isolate low frequency behavior and show that, with significant departures over some periods of time, income per capita grew, on average, at $1.2 \%$ per year. The decomposition shows that the largest departure from this behavior is the period from 1974 to 2010, when there was a large and sustained deviation from the trend, with two subperiods of rapid convergence. Using a simple version of Solow's growth model as a conceptual framework, we focus our analysis on that particular period. We calibrate and simulate the model from 1950 onwards and use its predictions to provide a quantitative measure of the extremely poor performance of the Argentine economy since 1974. We also use a simple model of the government budget constraint to account for the macroeconomic history of Argentina during that same period. We argue that the systematic mismanagement of government budgets is the principal reason for Argentina's long departure from the trend. The two subperiods of rapid convergence coincide with the two subperiods of macro fiscal discipline.
\end{abstract}

JEL classification: E42, E63, H63

Keywords: Macroeconomic instability, Argentina's stagnation, fiscal deficit, debt accounting

\section{INTRODUCTION}

In this paper we develop a specific view of the historical evolution of income per capita in Argentina with a special focus on the 1974-2010 period, which we argue is the most intriguing.

In May 25, 1810, a revolution in Buenos Aires ended the colonial government headed by the Spanish viceroy and the first local government was established. The war for independence lasted less than a decade, but it was followed by a period of alternating civil wars that lasted for

\footnotetext{
* This paper reflects our personal views and does not represent those of either the Federal Reserve Bank of Minneapolis or the Federal Reserve System. We wish to thank Felipe Zurita for the invitation to present this work at the 2010 Bicentennial Conference at the Pontificia Universidad Católica de Chile. ** Minneapolis Fed and UCLA. E-mail address: fjbuera@econ.ucla.edu

*** New York University. E-mail address: gaston.navarro@nyu.edu

**** Minneapolis Fed and Di Tella. E-mail address: juanpa@minneapolisfed.org
} 
another four decades. After the battle of Pavon in 1861, the civil war was finally ended and the country was unified. Afterwards, Argentina experienced one century of reasonable growth in income per capita, with a rate of about $1.2 \%$ per year between 1885 and 1965 . By the end of the 1960s, just over a century after the political consolidation of the country, per capita income was equivalent to $\$ 8,500$ in 2010 U.S. dollars, close to $50 \%$ of per capita income in the United States, the wealthiest country in the world. However, his period was not without crises, arising either from domestic or foreign shocks. For instance, in 1890, a largescale domestic financial crisis had an important impact on income per capita, causing it to decline $22 \%$ between 1889 and 1891. Also, World War I and the Great Depression had severe effects, with GDP declines relative to trend of $26 \%$ between 1913 and 1917 and 20\% between 1929 and 1932. Starting in the early 1970s, the behavior of income per capita changes dramatically. This was also a period of recurrent crises. The output drop, relative to trend, was $15 \%$ between 1987 and 1989 and $28 \%$ between 1988 and 2002. But the most significant difference between the two countries is that income per capita in Argentina in 2004 was the same as it had been in 1974. Never before, over a period of three decades, had income per capita stagnated as it did then. The 19742010 period is quite heterogeneous, and we will discuss this in detail. But to a great extent, the last 40 years of Argentinean macroeconomic performance is quite different from the rest of its history.

In the first part of this paper, we use a statistical decomposition of the data and then a simple growth model to make this statement quantitatively precise. That is, we show that, using two particular metrics, the period 1974-2010 is quantitatively different from 18601973, unlike any other subperiod.

In the second part of the paper, we briefly review Argentina's macroeconomic history during that period, using as a conceptual framework a simple model of the government budget constraint. The driving force of that budget constraint is the evolution of the fiscal deficit, with its implications for total government debt. We document the main events of the period and link them to the state of that budget constraint. As we show, the main characteristic of the period under study — with important exceptions during part of the 1990s and particularly from 2003 to 2008 - is the presence of high, chronic fiscal deficits. Finally, in Section 3, we construct a theoretical hypothesis that explains the stagnation period that is consistent with the historical evidence. We argue that the reason for Argentina's stagnation is the 
recurrence of government administrations that are unable to pay for its economic obligations. We propose a mechanism that explains why unsustainable fiscal policies lead to chronic stagnation.

\section{The EVOlution OF INCOME PER CAPITA, 1860-2010}

In Figure 1, we plot the logarithm of GDP per capita for Argentina between 1885 and 2010, setting the value of the beginning of the sample at 1. For the 1885-1900 period, we use GDP data from Gerchunoff and Llach (1998), for the years 1900 to 2004 we use data from Garcia-Cicco, Pancrazi and Uribe (2010) and from 2004 onward we use data from Instituto Nacional de Estadistica y Censos (INDEC). ${ }^{1}$ For population, we use data from Orlando Ferreres (2005) for the 1885-2004 period and the remaining years from INDEC. We also plot a curve that is equal to per capita GDP in 1885, the beginning of the sample, and grows at $1.2 \%$ a year. As can be seen from the data, a growth rate of per capita income equal to $1.2 \%$ provides a reasonable approximation to the long-run behavior of the Argentinean data. The figure suggests that behavior varies starting in 1974 .

\section{Figure 1. Per capita GDP (in logs)}

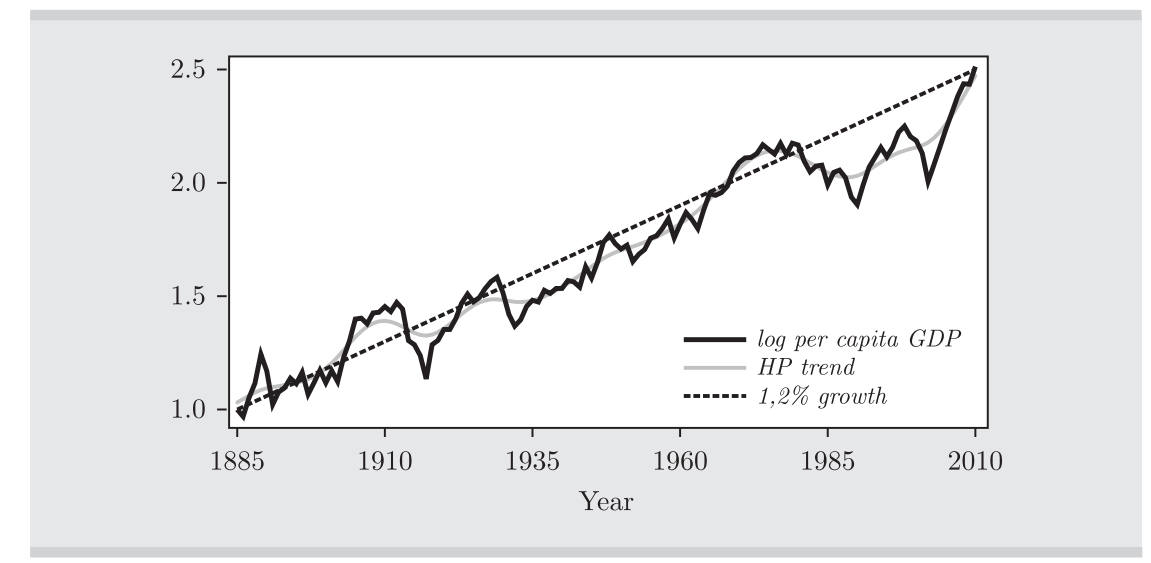

Sources: GDP: For the 1885-1900 period, Gerchunoff and Llach (1998); for the 1900-2004, Garcia-Cicco, Pancrazi and Uribe (2010); from 2004 onward, INDEC. Population: For the 1885-2004 period, Orlando Ferreres (2005); from 2004 onward, INDEC.

1. There is debate regarding the quality of INDEC data starting in 2007, due to an intervention by the government. If we were to replace the INDEC data with private estimates, the picture would hardly change. The only conclusion that differs depending on the data used is the size of the gap between current output and trend in 2010 . 
In what follows, we construct measures to make this statement precise. We first use a statistical decomposition of the data to separate high and low frequency components. Using the decomposition, we construct a first measure of stagnation that, although not based on theoretical considerations, is a simple way to summarize the data. An advantage of this exercise is that we only need data for per capita GDP, so we can start the analysis in 1885 . We then use a simple growth model to construct theoretical measures of GDP per capita that can be used to construct a second measure of stagnation. The virtue of the second exercise is that it uses a theoretical model that provides a truly out-of-sample forecast, and in that sense, it is more satisfactory. The drawback is that due to data availability limitations we can only perform that exercise for data from 1950 onwards.

As we will show, the measures do differ. Depending on the approach, the prospects for Argentina in the next decade are different. However, a general message emerges from the two exercises: The period that starts in 1973 is very different from any period in Argentina's history, which is why the remainder of the paper deals with that period.

\subsection{Statistical decomposition}

In order to isolate behavior over long periods of time, we filtered the log of per capita GDP using Hodrick-Prescott's filter, with the usual yearly value for the parameter, 100. Figure 1 also depicts the value for the low frequency component of the series. Figure 2A depicts the high frequency component of the series. Several features of the figures are worth emphasizing.

First, the high frequency (or business cycle) component in Figure 2A suggests that there are three periods in terms of volatility. ${ }^{2}$ The first period starts in 1885 and continues until the trough of the Great Depression in 1933. The volatility of the business cycle component is 0.06 for this period. The second period starts in 1933 and ends in 1974, corresponding to the period in which an import-substitution strategy was implemented in countries throughout Latin America, of which Argentina is one example. The volatility for that period goes

2. The choice of subperiods is, like many other things in this paper, arbitrary. We do believe, however, that this is a useful way to be arbitrary, since the division also corresponds to different stages in terms of the historical characterization of broadly defined economic policies. The rolling volatility exercise below supports, we believe, our choice of subperiods. 
Figure 2A. The high frequency component of GDP per capita 1985-2010

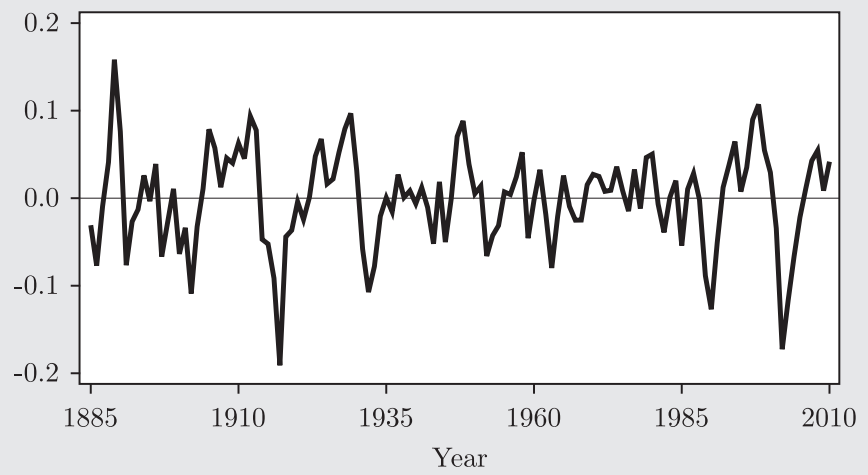

Figure 2B.Rolling volatility for 15- and 21-year windows

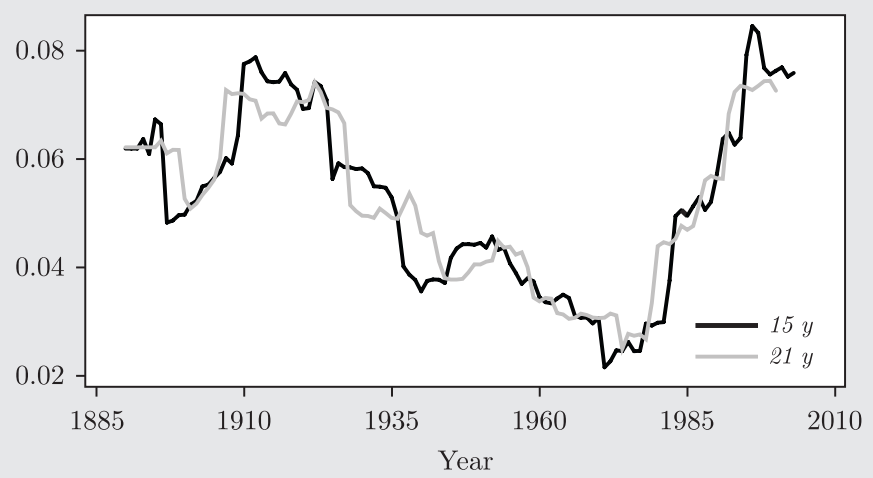

Sources: GDP: For the 1885-1900 period, Gerchunoff and Llach (1998); for the 1900-2004 , Garcia-Cicco, Pancrazi and Uribe (2010); from 2004 onward, INDEC. Population: For the 1885-2004 period, Orlando Ferreres (2005); from 2004 onward, INDEC.

down to 0.03. The third and final period is the one we focus in this paper, 1974-2010, when volatility increases again to 0.06. Second, what drives the high volatility values in the first and third sub-periods are several economic crises of tremendous magnitude. Indeed, between 1885 
and 1933, there are three mayor crises: the 1890 financial crisis, which was largely domestic; the 1915-18 crisis, which was caused mainly by World War I; and finally the crisis of the Great Depression. There is no crisis of the same magnitude between the Great Depression and the 1989-91 crisis, which was followed a decade later by the worst in Argentina's history. ${ }^{3}$ As a matter of fact, these two crises were the cause of the increased volatility in the final subperiod--the volatility for the period 1973-1988 (0.03) is the same as the volatility between 1933 and 1973. In Figure 2B, we plot the rolling volatility for 15- and 21-year windows, where this feature becomes clear.

In our opinion, the most striking feature of the decomposition is the behavior of the low frequency component. To make the point in a more direct way, Figure 3 depicts the difference between the log of per capita GDP and the straight line in Figure 1-the log of a curve that grows at $1.2 \%$. The natural interpretation of the curve is the percentage deviation of GDP relative to a $1.2 \%$ trend. While there are natural fluctuations around the $1.2 \%$ trend, it provides a decent approximation to the longrun behavior between 1885 and 1975. The value of per capita income is $15 \%$ higher than the $1.2 \%$ trend in the first decade of the 20th century and $10 \%$ below trend right after the Great Depression. Then increases to $10 \%$ above the trend once again in the early 1970s. But an obvious gap starts to open that year, so that per capita income drops to more than 35 percentage points below trend in less than two decades. It remained below trend for 30 years, with an average gap between 1981 and 2010 of almost $18 \%$ of the trend. The very high growth rates beginning in 2003 imply, according to this measure, that the gap has already been closed. To the extent that those growth rates reflect a convergence towards a trend of per capita growth of $1.2 \%$ and assuming that this trend summarizes the ability of Argentina to grow in the long run, as it did during the last century and a half, then the expectation is that growth rates will slow down significantly in the next decade. Of course, this does not necessarily have to occur. After all, our analysis lacks theoretical foundations. So far, we only provided a statistical description of the data. That description suggests to us a remarkable regularity: A simple $1.2 \%$ growth rate per year rule describes almost 150 years of long-run behavior of income per capita. To the extent that events repeat, the description is useful. To move forward, however, we need some theory, which is provided in the next section. 
Figure 3. Percentage difference between data and $1.2 \%$ trend

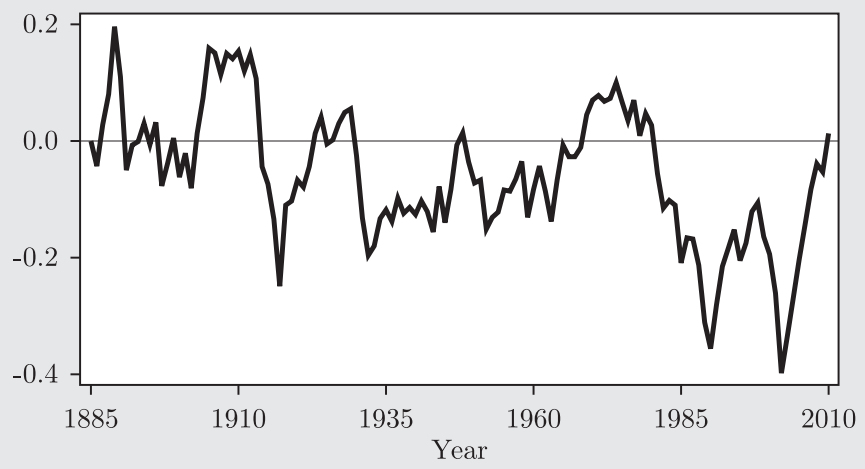

Sources: GDP: For the 1885-1900 period, Gerchunoff and Llach (1998); for the 1900-2004 , Garcia-Cicco, Pancrazi and Uribe (2010); from 2004 onward, INDEC. Population: For the 1885-2004 period, Orlando Ferreres (2005); from 2004 onward, INDEC.

\subsection{Predictions from Solow's model}

As a complementary exercise, in this subsection we use a quantitative version of a Solow growth model to generate an out-of-sample forecast of trend GDP for the period 1950-2010. A comparison of the model's forecast with the realized values of the variables provides an alternative measure of Argentina's underperformance since the mid-1970s.

Solow's model is given by a capital accumulation equation:

$$
K_{t+1}=(1-\delta) K_{t}+I_{t}
$$

a production function

$$
Y_{t}=A_{t} K_{t}^{\alpha} L_{t}^{1-\alpha}
$$

an investment equation

$$
I_{t}=s Y_{t}
$$

and exogenous laws of motion for labor and productivity

$$
\begin{aligned}
& A_{t+1}=A_{t}(1+g) \\
& L_{t+1}=L_{t}(1+n) .
\end{aligned}
$$


Note that in order to solve the model numerically, we need starting values for productivity, employment and capital $\left(K_{0}, L_{0}, A_{0}\right)$, and values for the parameters $(\alpha, s, \delta, n, g)$. In order to obtain an estimate for $g$, which is a key parameter, we need data for capital and labor; however, no reliable data going back to 1885 exists that we know of. However, there is data starting in 1950, so we use that data to calibrate the model in that year.

We use data for output, employment, capital and total factor productivity in 1950 from Corememberg et al. (2007). The data has also been used by Ferreres (2005), who provide alternative interpretations of some of the events we also study. Using the data on investment from Garcia-Cicco et al. (2010) and a depreciation rate of $4 \%$, we compute backwards the capital stock using ${ }^{4}$ Equation (1) for the period 1930-1949. Similarly, we project backwards the employment data, using population growth rates. ${ }^{5}$ We follow Hevia et al. (2011) and set $\alpha=0.32$. Then, given our constructed data for inputs and the data for output used in Figure 1, we use (2) to construct values for $A_{t}$, between 1930 and 1949. Finally, with the constructed series for $\left(K_{t}, L_{t}, A_{t}\right)$ for $t=1930, \ldots, 1949$, we compute average values for the remaining three parameters of the model $(s, n, g)$ for the period 1930-49. Finally, using the initial values for 1950 and the five parameters

$$
\alpha=0.32, s=0.15, \delta=0.04, n=0.018, g=0.011
$$

calibrated using data from 1930 to 1949, we can forecast the evolution of GDP from 1950 to 2010. We would like to emphasize that the simulation does not use any information posterior to 1950. Thus, this exercise could have been carried out by any economist in 1950, except for the fact that Solow's paper was yet to be published.

Figure 4 presents the evolution of GDP together with two different simulations. Note that the data in the figure is total GDP, not per capita GDP, so it is not comparable with the data in Figure 1. The reason we focus on total GDP will soon become clear. The first simulation, labeled $(n+g)$, is the one discussed above, where the growth rates of population and total productivity are set equal to their average

4. The numbers do not change noticeably when depreciation rates between $3 \%$ and $4.5 \%$ are used. Higher numbers imply very implausible values for capital in the first decades of the 20th century.

5. We do not have employment data. In the model, employment grows at the same rate as population. 
values between 1930 and 1949. The second is very similar, but the growth rate of productivity is set to zero, so the only two remaining forces for growth are transitional dynamics and labor input growth.

Figure 4. Per capita GDP and simulation of Solow's Model, 1950-2010

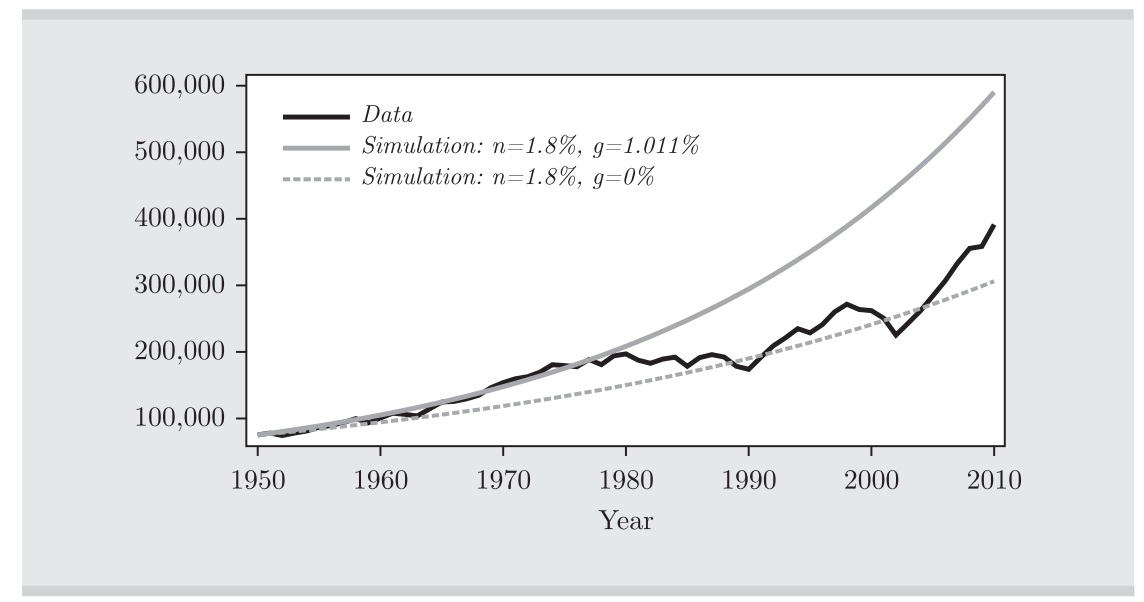

Source: Per capita GDP and simulation of Solow's Model, 1950-2010.

Note that the prediction of the model is very good only until the mid-1970s. Remember that the simulation does not use data after 1950 , so this is really an out -of-sample exercise. ${ }^{6}$ In addition, the model without productivity growth grossly underestimates the data from 1950 to 1975. However, the picture changes drastically around 1975: The data departs from the prediction of the productivity growth model and converges to the no-productivity growth model in about 10 years. It recovers in 1991, but reverts back to it by 2000 . A possible interpretation, a one we particularly like, is that for some reason $^{7}$ the Argentinean economy stagnated persistently in the last 25 years of the 20 th century. This meant that income per capita in 2000 was equivalent to what Solow would have predicted, assuming no productivity growth. Thus, whatever Argentina did wrong (the

6. A closer look at the data between 1950 and 1975 shows that the forecast makes two mistakes in opposite directions that roughly compensate each other. The 1950-75 investment rate was a bit higher than that of the previous two decades, but the growth rate of productivity was a bit lower than in the two previous decades.

7. Our preferred hypothesis is spelled out in the last section of the paper. 
gap in the figure undoubtedly implies that a significant mistake was made), it was very costly as it rendered 50 years of productivity growth unproductive.

The economy's recent period of recovery, which started in 2002, again generated a process of convergence towards the prediction of the model with productivity growth. In Figure 5, we jointly plot the prediction of the Solow model for per capita GDP and the data. ${ }^{8}$ We conclude this section with a measurement of the gap between observed per capita income and the prediction from Solow's model in a fashion similar to the one depicted in Figure 3. There is an important difference between the two measurements of the gap: According to Solow's model, the convergence has not been fully achieved and there are 20 percentage points' difference between the data and the prediction. This is important, since the model suggests that, all else being equal, growth rates will still be substantially above trend for several years in the next decade. But there is a common message: The period beginning around 1974 is of a very different nature than any other subperiod of Argentina's economic history. We proceed to analyze that period next.

\section{Figure 5. Per capita GDP and simulation of Solow's Model, 1950-2010}

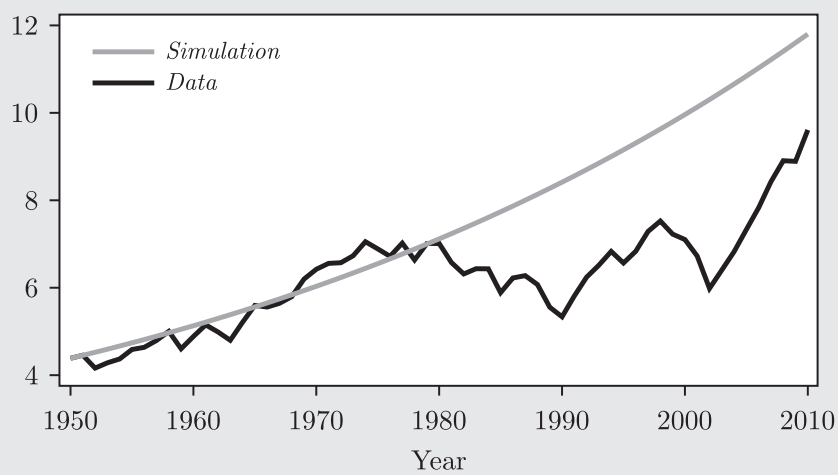

Source: Data on output, employment, capital and total factor productivity in 1950 from Coremember et al. (2007).

8. The gap is smaller than it is for total GDP, since according to the data, population growth was lower between 1950 and 2010 than between 1930 and 1949, which is the growth rate that was fed into the model. 
Figure 6. Gap between data and simulation, 1950-2010

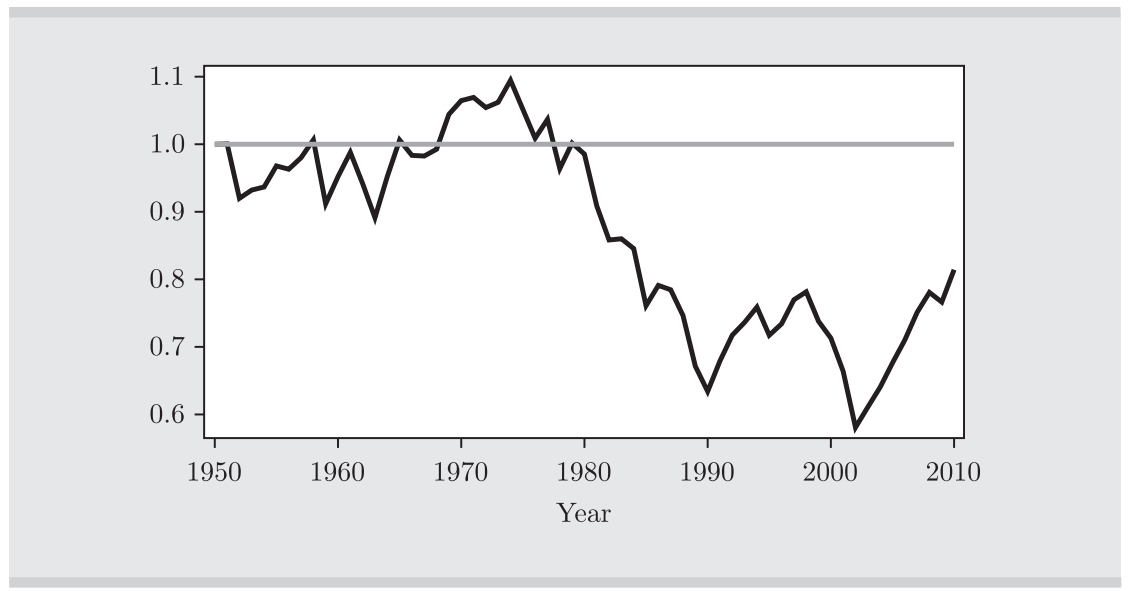

Source: Data on output, employment, capital and total factor productivity in 1950 from Coremember et al. (2007).

\section{A HistoRY OF MACROECONOMIC INSTABILITY: 1974-2010}

Starting in 1974, Argentina entered a period that is very different from its previous history. While it is true that the volatility was higher than during the 1930-1974 period, it is very similar to volatility from 1885 to 1930. In addition, volatility between 1973 and 1988, the worst period in terms of growth, is very similar than between 1930 and 1974 . The remarkable feature of the 1974-2010 period, therefore, is the break in the trend of output per capita.

In this section, we provide a historical account of the macroeconomic evolution of the period, focusing on the behavior of the government's fiscal deficit and government debt. We briefly discuss, in the first subsection, a simple conceptual framework. In the second subsection we provide a narrative account of the main macroeconomic events using the simple conceptual framework. In the final subsection, we establish our hypothesis in detail and argue in its favor.

\subsection{The economics of budget constraints}

Sargent (1983) uses a simple budget constraint approach to analyze episodes of nominal instability, essentially understood as inflationary episodes. It is worth pointing out though that balance of payment 
crises and often also banking crises are associated with inflation. ${ }^{9}$ All of these phenomena are present in the period analyzed.

If we let $D_{t}$ be the government deficit in nominal terms, measured as expenditures and transfers minus taxes, $B_{t}$ and $M_{t}$ the stock of government debt and money, and $R_{t}$ the nominal interest rate, then the budget constraint of the government can be written as: ${ }^{10}$

$$
\left(B_{t+1}-B_{t}\right)+\left(M_{t+1}-M_{t}\right)=D_{t}+B_{t} R_{t}
$$

The right-hand side of the Equation represents the financial obligations of the government in the period, while the left-hand side represents the two ways the government has to finance them, by either issuing interestbearing debt or non-interest-bearing debt (money). A direct implication of this budget constraint is that sustained deficits may not lead to inflation. This will be the case if the debt is managed - increased - to finance all obligations. However, if for some reason the government is unable to borrow, then the only source of financing is money creation. But a systematic increase in the money supply inevitably leads to systematic inflation. Alternatively, one can imagine a monetary regime that implies a very small rate of money growth, like a currency board or a currency union. Imagine, for the sake of the argument, that it is zero. Then, sustained deficits lead to very high levels of debt and default may follow. Sustained deficits, therefore, lead to inflation, default or a combination of both. In a nutshell, this is the macroeconomic history of Argentina since 1974.

Generally, there is in general an important accounting issue in the definition of fiscal deficit. In principle, government accounts include current expenditures that are part of the approved budget. However, in many instances, governments incur unexpected expenses that do not go through the normal budgetary process. A banking crisis where there is deposit insurance would be a simple example. Deposit insurance implies a contingent liability that materializes in the case of bank failures. In many instances, governments issue special bonds to finance those contingencies, which are not always accounted for in deficit figures. As we will show, this is an important factor in Argentina during the period, so the evolution of debt may not be consistent with official deficit data at all times.

9. A remarkable exception is the banking crisis of 1995 .

10. Note that we treat interest payments separately in the budget constraint, so our definition of deficit does not involve interest payments. Instead, it is simply the difference between current nominal expenditures and current nominal tax revenues. 
In Figure 7 we plot the yearly deficit and the yearly inflation rate. ${ }^{11}$ All the data used in the rest of the paper is from Buera and Nicolini (2009). Sargent's story fits the data well in a qualitative sense, as long as we assume that the government's ability to borrow was very limited. The three years with the highest inflation rates - 1975, 1985 and 1989-are the three years in which the deficit peaked. It also seems clear that the story has some quantitative problems: for instance, the deficits in 1988 and 1989 are similar to the ones in 1981 and 1982 and the inflation rate was five times higher. ${ }^{12}$ In the approach described above, the exogenously imposed debt limit is important, since once the government hits that constraint, the direct relationship between deficits and inflation arises. On the other hand, once that limit is reached, default is also a possibility. Our narrative discussion will attempt to explain why the adjustment was made in one direction at certain times and in other directions at other times. But in the end, we argue that the effect of chronic deficits on real activity does not depend on the particular way the government eventually adjusts its finances, but rather on the need to take dramatic and unexpected actions to adjust them.

\section{Figure 7. Ratio of deficit to GDP (left) and inflation (right)}

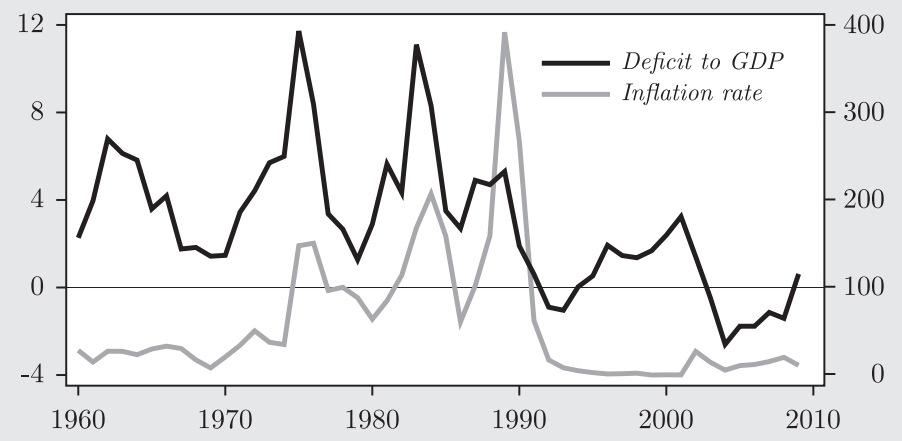

Source: Schenone (1987); Informe Económico Trimestral (several issues), BCRA; and Informe Económico (several issues), Ministerio de Economía.

11. The inflation rate is defined as $\log \left(P_{t+1} / P_{t}\right)$.

12. Marcet and Nicolini (2003) and Sargent et al. (2009) provide quantitative explanations using the same conceptual framework, in models with quasi-rational learning. 


\section{The BOP crisis version}

Sargent's story can also accommodate balance of payments crises when countries choose, as Argentina repeatedly did during this period, to fix the nominal exchange rate. An articulated model is provided in Krugman (1979). The approach uses a version of purchasing power parity with arbitrage conditions for the price of traded goods in open economies, i.e.,

$$
P_{t}=P_{t}^{*} \cdot e_{t},
$$

where $P_{t}$ is the domestic price level, $P_{t}^{*}$ is the price level of the foreign country to which the domestic currency is pegged, and $e_{t}$ is the nominal exchange rate. The second key component of the theory is a version of a demand for money. We use the quantity theory, that reads

$$
M_{t} v=P_{t} y_{t},
$$

where $v$ is the velocity of money, assumed to be constant, and $y_{t}$ is real GDP, determined in the real sector of the economy. To simplify, let us assume that the relevant monetary aggregate is the monetary base. From the balance sheet of the Central Bank,

$$
M_{t}=R_{t}=D C_{t},
$$

where $R_{t}$ is the Central Bank's stock of international reserves and $D C_{t}$ is the stock of domestic credit. The first Equation determines the domestic price level as long as the nominal exchange rate is fixed. The second Equation then determines the nominal quantity of money.

Thus, the total amount of nominal money cannot be increased by the Central Bank, and any attempt to do so by increasing domestic credit will imply a reduction of the stock of international reserves.

The story then, goes like this: Sustained deficits and the inability to borrow force the Central Bank to increase domestic credit. This increase in domestic credit forces a loss of international reserves. To the extent that the deficits are sustained, the nonnegativity restriction of international reserves will eventually be binding, inducing a balance of payments crisis, a devaluation and inflation ${ }^{13}$. Again, the inability to borrow is a key component of the theory.

13. The interesting twist in Krugman is to make the demand for money dependent on the nominal interest rate to generate a "run" on the domestic currency. 
To summarize, at a first glance the deficit seems to be the main explanation for the Argentinian crisis. Thus, a Sargent type of story fits the data and describes the experience. Why is debt important? From a theoretical point of view, it is important because Sargent's analysis depends on the country having reached the credit constraint. In the model the debt limit is exogenous, so there is not much else to say. How does a country reach the limit? It is possible that a government accumulates deficits over a long period of time such that it eventually and gradually reaches the limit. That is indeed possible, but as we will show, it is not the whole story.

During periods in which the government is in default, the ability to issue new debt is quite limited. If monetary policy is not targeting the exchange rate, when short term measures to finance the deficit prove insufficient, inflation explodes. Thus, fiscal imbalances translate into high and very volatile inflation, which typically implies substantial short-run fluctuations in the real exchange rate. The ex-post dollar returns of short-term financial investments are large and extremely volatile. Alternatively, when monetary policy targets the exchange rate, inflation is low and stable, and nominal returns in domestic currency depend on the expectations of devaluations. Eventually, when a BOP crisis unfolds there is a sharp devaluation that also makes the real exchange rate volatile. Again, the average real returns are high and their volatility even higher. In all cases, the realization of uncertainty implies larger redistributions of wealth.

\subsection{Macroeconomic and debt evolution}

The analysis of the paper covers roughly the period starting in the early 1970s until the late 1990s. As the focus is on the behavior of government finances, we divide this discussion into four periods according to the evolution of the deficit and debt, which determined the government's ability to borrow in domestic and foreign markets.

Figure 8 shows the evolution of the debt-to-GDP ratio between 1973 and 2009. Using these data, we set the first period from 1973 to 1976. During these years, the economy was closed to capital movements. Debt as a share of GDP was small and consisted mainly of domestic debt. For instance, in the early 1970 s the debt-to-GDP ratio was around $7.5 \%$, while foreign debt accounted for only $20 \%$ of that. The first years of the decade were characterized by fiscal deficit close to $2 \%$ of GDP, as can be seen in Figure 7. Because of the closed economy, the government 
had no access to foreign borrowing and deficits were therefore financed by either domestic debt or seniorage. In 1973 and 1974 the deficit jumped to $6 \%$ while in 1975 it skyrocketed to $12 \%$. These higher fiscal imbalances were financed by both seniorage - 1975 is the year of the first hyperinflation of the period studied - and by domestic debt. Thus, by the end of 1976, the debt-to-GDP ratio was over $20 \%$.

\section{Figure 8. Debt-to-GDP ratio}

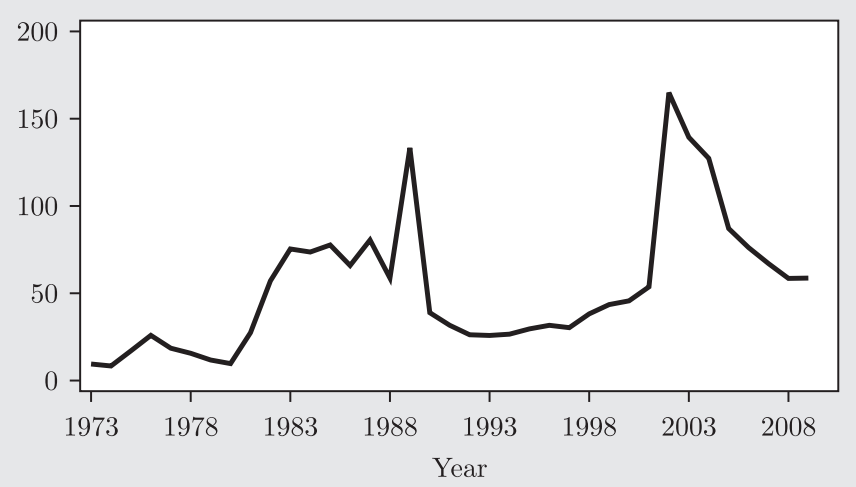

The second period covers roughly 1977 to 1982, the beginning of the debt crisis. This period was characterized by a substantial reduction in tariffs and the opening of the economy to the international capital market. Two additional policy changes were key to determining the evolution of the debt. First was the deregulation of the financial sector. This deregulation implied that the interest rate was determined by a free market and there was free entry to the industry. These reforms, together with the implementation of a deposit insurance guaranteed by the government, are key to understanding the development of government debt over the following decade, as we argue later on. Deposit insurance is government contingent debt because in the event of a banking crisis, the liabilities of the financial sector become liabilities of the Central Bank. The second policy change was the stabilization attempt launched in 1978, which included a pre-announced crawling peg. To support the credibility of the plan, an exchange rate guarantee was offered by the government. This period was characterized by 
access to international capital markets and the government financed the deficit with foreign debt, mainly bank debt.

By the end of this period, a generalized banking crisis forced the government to back an important portion of deposits. At the same time, a balance of payment crisis developed that led to a sharp devaluation of the domestic currency. The exchange rate guarantee implied an additional burden for the government.

Starting in 1982, the government was unable to comply with its debt obligations and unilaterally declared default. This event forced the government out of the international capital market until 1991, so fiscal imbalances had to be financed by either domestic credit or seniorage. This period witnessed two hyperinflations and several balance of payment crises. One of these crisis years was 1989. A balance of payment crisis evolved into hyperinflation, which reached more than $200 \%$ per month in June in that year. A stabilization period began in July 1989 and there were two additional, important developments in regard to the evolution of government debt: The Bonex plan of January 1990, which swapped short-run bank deposits for long-term bonds, and the Brady plan in 1992, which consisted of an agreement with creditors to end the default period.

The Brady plan marked the start date of the following period, in which a currency board was imposed and a period of improved confidence in international capital markets began. The government was able to float bonds abroad and after several years of stability, in 1998 the interest rate paid was only a few points above the T-bill rate. The most interesting episode in this period is a severe banking crisis that developed in early 1995, following the turmoil in international capital markets related to the Mexican devaluation of December 1994. Argentina's economy recovered very quickly, and growth rates were quite high in the aftermath of the crisis. In 1998, following a series of financial crises in developing economies, a recession started that lasted until 2000. That year, a significant fraction of debt was due and this fraction would climb even higher in the years to come. The recession continued and the capital account reversals following the financial crises in Asia and Russia placed an excessive burden on a government that had been running deficits since 1995. The default at the end of 2001 was the unavoidable outcome. The default, together with the exit from the currency board in a highly dollarized economy, caused the largest drop in per capita GDP in Argentina since World 
War I, as can be seen in Figure 2A, which depicts the high frequency component of income per capita. A new period starts in 2003, and is characterized by being the longest period of substantial government surpluses in Argentina's recorded history. An offer was made to defaulted creditors to swap the defaulted bonds for new bonds, with a haircut that is reflected in the graph. Over $80 \%$ of the bondholders accepted the offer, while the remaining bonds are still on default.

These developments are relevant to understanding the dynamics of total government debt, depicted in Figure 9. The figure represents total federal government debt, including bonds, banking debt, debt to other governments and financial institutions. It is denominated in 1996 U.S. dollars. Total debt increased substantially from 1975 to 1982 , with a yearly average of $30 \%$. This is the period in which the government borrowed abroad to finance not only the deficit, but also the "contingent debt" implied by the deposit and exchange rate insurance. Then the debt crisis developed and government debt grew at a much lower rate. In fact, the debt level in 1991 was slightly above the figure for 1983. Changes in the stock of debt are related to the accumulation of arrears and the issuing of domestic bonds, some of them voluntary, some of them mandatory. Starting in 1991, as the government regained access to international capital markets, the debt started to grow again, with an average yearly rate of $10 \%$. The 2001 crisis was extremely expensive for the government, which is reflected in the spike in debt in 2002: The government carried out a large issuance of bonds to cover exceptional expenses, including transfers to the banking system to compensate banks for the asymmetric treatment of dollar-denominated bank assets and liabilities. Finally, the reduction of total debt in 2005 corresponds to the haircut obtained in the offer made to defaulted bondholders.

Two phenomena affect the evolution of the debt-to-GDP ratio. The first one is obvious: GDP growth. The second, which was very important for Argentina during that period, consists of real exchange rate movements between the peso and the dollar. The GDP, as well as peso-denominated debt, are deflated using peso price indices, while the dollar-denominated debt is deflated using U.S. price indices and the nominal exchange rate between the peso and the dollar. Any deviation from PPP will affect the figure. This is important to take into account, because there are strong movements in the debt-to-GDP ratio that are not associated with fiscal policy but rather with relative price changes, and there were substantial relative price changes in Argentina during 
Figure 9. Total government debt (1996 million U.S. dollars)

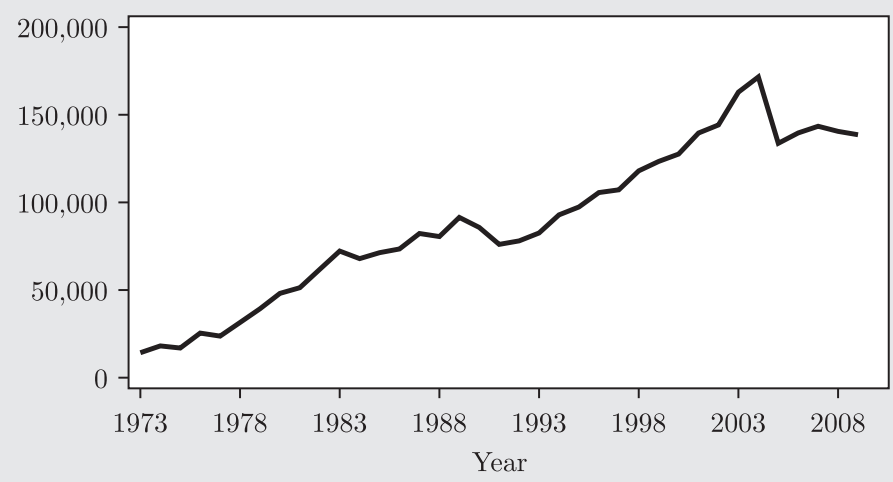

Figure 10. Actual and simulated debt-to-GDP ratio

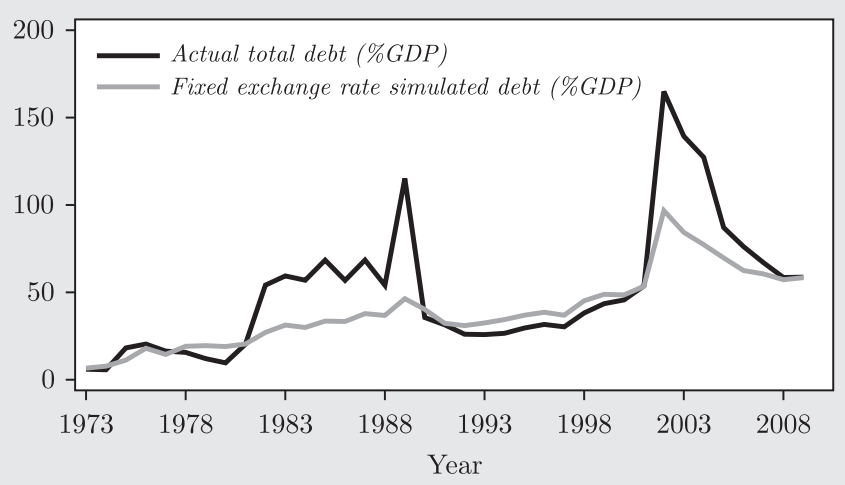

the period considered here. To provide a quantitative measure of this effect, Figure 10 depicts the debt-to-GDP ratio keeping constant the real exchange rate at its 2001 value.

These two effects explain that while total debt increased from almost US\$ 20 billion to almost US\$ 50 billion from 1975 to 1980, the debtto-GDP ratio actually fell. While GDP grew during the period, it 
obviously did not grow at the same magnitude as debt. What explains this behavior is a strong appreciation of the peso, which reduced the relative value of dollar-denominated debt. The sharp increase in the debt-to-GDP ratio in 1982 reflects the strong depreciation of the peso. Thus, the period is characterized by an increase in the debt-to-GDP ratio which is smooth if we abstract from real exchange rate movements.

The relatively flat segments of the lines in Figure 10 during most of the 1980s reflects the government's limited access to credit markets. The spike in 1989 is essentially explained by a significant depreciation of the peso and, to a lesser extent, a strong recession. The third period is characterized by a somewhat steady and lower value of the ratio. Again, an important explanation for this lower value is the appreciation of the peso and the high growth rates experienced by Argentina during the period. Another important factor is the privatization of stateowned companies in the beginning of the decade. The government accepted its own bonds as a means of payment in the auctions, so to some extent, the privatization process was a bond-company swap. The ratio increased steadily during the 1990s until the 2002 default. The figure also makes clear that the default did not reduce the debt-toGDP ratio, since the government issued large amounts of debt during the crisis. In 2002, the debt-to-GDP ratio begins to fall as a result of GDP growth, appreciation of the peso and the haircut of 2005 .

Overall, these figures show that although the average debt-to-GDP ratio is low, exposure of this number to real exchange rate fluctuation is important. More than 90 percent of the debt is dollar-denominated, so a crisis entailing a real exchange rate depreciation would substantially affect that ratio. For instance, to increase the debt-to-GDP ratio from $25 \%$ to $40 \%$, the government must have a deficit (including interest payments) that is three points higher than the growth rate of output sustained for 10 years. A crisis that results in a 50\% real depreciation-a number that is in line with the recent experience - would achieve that change instantaneously. Again, the reason for this is that more than 90 percent of the debt is indexed to the exchange rate rather than to domestic price levels.

In summary, the behavior of government debt is explained by fiscal policy as usual plus two other main features. First, the occurrence of states against which the government had insured the private sector through exchange rate insurance and deposit insurance. To the extent that the nominal exchange rate is devalued or banks go bankrupt, the 
liabilities of other private debtors in dollars become partial or total liabilities of the government. This explains the substantial increase in debt from 1980 to 1983. Second, fluctuations in the real exchange rate affect the value of the debt substantially to the extent that most of it is indexed to the nominal exchange rate.

\section{The hypothesis}

Let us focus first on the depression from 1998 to 2002. In some aspects, this was similar to the Great Depression of the early 1930s in the U.S.: Both saw a profound drop in real GDP, extremely high unemployment rates and bank runs. But there are major differences. The Argentine government defaulted in its debt and the 2001 depression was, for Argentina, at least the fourth crisis since 1975. Thus, while the 1929 crisis was a surprise to many, the crisis of 2001 was the outcome of a (yet another) slow deterioration in the government's fiscal position that had begun in 1995 and became unsustainable by 2001. Thus, while there is some debate about the role that policy played in the management of the 1929 crisis, poor government policy was not the cause.

We argue that mismanagement of macro fiscal policy is the main reason for the crisis in Argentina in 1999-2001. We also argue that the same mismanagement has caused all previous crises since 1973. Large budget deficits created the hyperinflationary situations of 1975, 1985 and 1989, as well as the debt increases from 1976 to 1983 and from 1993 to 2001. Although after 1991 there was a substantial reduction in budget deficits, they were not brought down enough to avoid the 2001 default. Paradoxically, in terms of debt-to-GDP ratios, the figure in 2005 - after the default — was larger than what it was in 2001.

The typical adjustment in each of these crises was a "fiscal surprise"; in 1975, this consisted of a burst in inflation (known as the "Rodrigazo") after a period of price controls. In 1980, it was a devaluation that abandoned a formally established crawling peg. There was also a deposit freeze and a default on foreign debt. A statement by one of the country's finance ministers during this time became famous: "Those who bet against the peso will lose." In 1985, immediately after the Austral plan was implemented to stop rampant inflation, an exceptional tax collection was imposed. In 1989, the country experienced its worst hyperinflation in history. In 1990, there was a new hyperinflation and mandatory swap of bank deposits - the same deposits financing the 
government via high reserve requirements and which paid market interest rates - for government bonds. In 2001, there was default, devaluation, and "pesification," or a mandatory exchange of dollardenominated deposits (and debt), to peso-denominated deposits (and debt) at an exchange rate $66 \%$ below the market value.

All of these situations led to major redistributions of wealth. For example, when the deposit freeze was mandated in 2001, the deposit-to-GDP ratio was around $30 \%$. The confiscation involved in the "pesification" amounted, therefore, to $20 \%$ of GDP. This is our estimate of the wealth that was redistributed from deposit holders to bank debtors. It should not come as a surprise that many banks were burned down in the aftermath of the crisis.

How could one become wealthier in Argentina during this period? By winning at in a zero-sum game. Each crisis involved an enormous redistribution. The returns of playing the redistribution game well are huge. Since 1970, there have been two periods of very rapid growth. The first lasted from 1990 until 1998. During this period, the government introduced trade reforms, privatized large, bankrupt state-owned companies, deregulated markets and reformed the existing pay-as-yougo pension system, switching to a private investment program. At the time, Argentina was the darling of the Washington Consensus. From 2003 until 2010, the government imposed price controls, repurchased companies that had been privatized, imposed very high export taxes, started up a large program of discretionary subsidies and micromanaged trade policy, and by the end of that period inflation had returned. Thus, none of the economic policies followed since 2003 would be in the list recommended by the Washington Consensus, except, of course, for fiscal discipline.

What the 1991-1998 and 2003-2010 periods had in common was macro discipline. In both periods, the way to become rich was the same as in the rest of the world: constantly trying to lower costs, which implies, in the aggregate, increasing total factor productivity. Lowering costs is a positive sum game. In contrast, between 1974-1991 and 1998-2002, the way to become rich in Argentina was to win at any of a plethora of zero-sum games created by the government when dealing with its bankruptcy in the most arbitrary ways. Therefore, these massive redistributions are zero-sum games with huge returns for the happy few: How can one compare a mere $4 \%$ increase in profits after a year of hard work reducing costs with $30 \%$ profits from being in the right 
side of a financial transaction during the right week of the year? Charles Ponzi dreamed of such rates of return in Boston before the Great Depression. Through its policies, the Argentinean government has made them happen repeatedly over the last three decades.

\section{Conclusions}

In this paper we focus on one potential explanation for the stagnation of Argentina's economy between 1973 and 2003. There are, certainly, competing hypotheses. Undoubtedly, our simplified model does not take into consideration issues and factors that are certainly important in shaping the events of these decades. For instance, the strong appreciation of the dollar and the rise in U.S. interest rates in the early 1980s was a key trigger of the default in 1982. Similarly, the Asian and Russian crises of the late 1990s paved the way for the 2002 default. We believe, however, that the effect of these shocks would probably have been less severe and certainly less persistent with different macro fiscal discipline.

Our simple explanation is that a long history of fiscal mismanagement created recurrent economic crises in Argentina during the last 35 years that were very costly in terms of GDP, employment and poverty. The main factor contributing to the crises was large fiscal budget deficits, so that while the particular symptoms of each crisis may vary, the force behind them was the same. While one estimate of the gap between per capita GDP and its long run trend says that Argentina has already reached its long-run trend, another estimate says that there is still a 20 percent gap to close. ${ }^{14}$

The implication of this hypothesis is that by ensuring macroeconomic stability through running sustainable macro fiscal policies, Argentina's economy will grow in the future, with either stationary growth rates for income per capita close to $1.5 \%$ in the worst-case scenario or with a transition of around five years of growing at rates close to $4 \%$ and then reaching steady growth of $1.5 \%$.

But there is another possibility: A return to uncontrolled fiscal deficits and the well-known ghosts of the past: inflation, devaluation, defaults, zero-sum games and stagnation. 


\section{REFERENCES}

Buera, F. and J.P. Nicolini (2010), "The fiscal and monetary history of Argentina," mimeo, Federal Reserve Bank of Minneapolis.

Coremberg, A., P. Goldszier, D. Heymann and A. Ramos (2007), "Patrones de la inversión y el ahorro en la Argentina," Serie Macroeconomía del Desarrollo 63, ECLAC.

Ferreres, O. (2005), Dos siglos de economía argentina (1810 - 2004): historia argentina en cifras. Fundación Norte y Sur: Buenos Aires, Argentina.

Garcia-Cicco, J., R. Pancrazi and M. Uribe (2010), "Real bussines cycles in emerging countries?," American Economic Review 100(5): 2510-2531.

Gerchunoff, V. and L. Llach (1998), El ciclo de la ilusión y el desencanto: un siglo de politicas económicas argentinas. Ariel Publications.

Hevia, C., H. Hopenhayn, and A. Neumeyer (2011), mimeo.

Krugman, P. (1979), "A model of balance-of-payments crises," Journal of Money, Credit and Banking 11(3): 311-325.

Lucas, R. and N. Stokey (1983), "Optimal fiscal and monetary policy in an economy without capital," Journal of Monetary Economics 12(1): 55-93.

Marcet, A. and J.P. Nicolini (2003), "Recurrent hyperinflations and learning," American Economic Review 93(5), 1476-1498.

Sargent, T. (1993), Rational expectations and inflation, Harpercollins Series in Economics.

Sargent, T., N. Williams and T. Zha (2009), "The conquest of South American inflation," Journal of Political Economy 117(2): 211-256.

Schenone, O. (1987), "El comportamiento del sector público en Argentina: 1970-1985", CEMA Working Papers 60. 